Julia Glathe

\title{
KNOWLEDGE, POWER, AND TRUST: THE ROLE OF EXPERTS IN RUSSIA'S MIGRATION REGIME
}

This article examines the role of experts in the field of migration policy in an authoritarian environment and their collaboration with the state in times of crisis. While much of the literature on migration policy-making in Russia focuses on patron-client relationships between state and business, little is known about the collaboration of state actors and experts. Therefore, this paper provides an overview of the main migration experts and shows the conditions under which they are involved in migration policy. Despite various forms of collaboration, expert policy networks are strictly controlled by Russia's authoritarian state. Measures of control include the sanctioning of foreign financing, a weak culture of dialogue, non-transparent political decisions, the absence of institutionalized political competition and an extremely personalized system of interaction that places experts in a relationship of dependence, thus preventing substantial criticism of political decisions and forcing loyalty. Since 2016, the conditions under which experts are involved in migration policy have become even more limited. It is argued that the reasons for the change are linked to a threefold loss of trust in the expertise of non-state actors, in particular, international organizations. This loss of trust can be explained firstly by a collision of the long-term logic of expert advice with the short-term crisis management of the state; secondly by a dynamic that followed from the institutional restructuring of the Federal Migration Service that dissolved long-standing personal relationships between experts and officials; and thirdly by a general loss of trust in Western policy solutions and liberal norms in the management of migration (crises).

Key words: Russia, migration policy, expert knowledge, authoritarian politics, civil society

DOI: 10.17323/727-0634-2020-18-4-751-764

Julia Glathe-PhD student in sociology at the Department of politics and social sciences, Freie Universität Berlin, Germany. Email: julia.glathe@fu-berlin.de 
When I first came to Moscow for my field research in 2017 to investigate the role of non-state actors in the Russian migration regime, I encountered the unanimous opinion in the expert community that an authoritarian backlash had taken place. After the adoption of a relatively liberal migration state concept in 2012, in whose development non-state experts played a major role, now all signs seemed to point towards a return to a strong state that would not tolerate any participation of society in political decision-making. To the horror of the expert community, the Federal Migration Service was abolished in 2016 and its functions were transferred to the Ministry of Internal Affairs. Shortly afterwards, a new migration project appeared, which bore a much more restrictive signature, and came into force one year later, at the end of 2018. All this happened against the background of the armed conflict in eastern Ukraine, which forced more than a million people to flee to Russia and the large influx of refugees to Europe, intensively discussed in Russia as the 'European migration crisis'. Despite (or perhaps because of) the global and local migration challenges, the Russian state increasingly monopolized migration policy in the sense that independent experts were almost completely excluded from any advisory function. How can this development be explained?

I argue that it is not enough to simply point to the undoubtedly existing clientelism and corruption in the Russian state, which can hardly explain this rapid change and also otherwise paints a rather limited picture of a state that despite authoritarian leadership is embedded in society. Several scholars, such as Sabine Kropp el al. (2017) have demonstrated various forms of collaboration between state and society in Russia in the light of increasingly complex political challenges. This also applies to the domain of migration policy, where interaction in the form of consultative councils, public chambers or grant schemes have taken place in recent decades (Aasland et al. 2016). This does not mean that this relationship is free or equal. The power of experts is certainly limited by the authoritarian state. And yet it is worth examining more closely the relationship between experts and the state to understand why it has fallen into crisis at a time when the need for expertise might seem particularly relevant.

Against this background, I seek to answer the following research question: what role do experts play in Russian migration policy under conditions of authoritarian rule and why did it run into crisis after 2014? To answer this question, I rely on thirty expert interviews conducted with leading migration experts in Russia between 2017 and 2019. The argument, developed in this paper, addresses the role of trust, which must be considered a prerequisite for a productive interaction between state and experts.

\section{Political Regulation of Immigration in Post-Soviet Russia}

Since the fall of the Soviet Union, Russia has become one of the largest immigrant destinations in the world. This is closely linked to the collapse of 
the Soviet Union, which 'has "internationalized" what previously counted as "internal" migration' (Brubaker 1992:269). Today Russia counts 11.6 million international migrants (Migration Data Portal 2019) and, according to official statistics, faces an annual influx of more than 700,000 people (Rosstat 2019). The vast majority comes from the post-Soviet space, which is why some authors speak of 'post-colonial migration' (Kuznetsova, Round 2019).

Migration scholarship often describes Russia's political response to largescale immigration as 'messy and paradoxical' (Light 2016: 2), excessively complicated and non-transparent (Malakhov, Simon 2018), 'full of inconsistent and conflicting tendencies' (Heusala 2018:431), 'overly restrictive' (Cook 2013:98) and shaped by 'high levels of corruption' (Round, Kuznetsova 2017:3). For most of the literature, the contradictory character is an expression of an authoritarian, patrimonial and populist state. From such a perspective, migration policy appears as a tool of political power within an informalized authoritarian system (Light 2016; Schenk 2018).

The present research offers insights into the migration policy of one of the largest immigration destinations. However, the strong focus on the state has so far provided insufficient insight into the role of social actors within the Russian migration regime. Given complex political challenges, the state shows an interest in cooperating with non-state actors and utilizes expert knowledge to effectively address social issues (Berg-Nordlie et al. 2018). Nevertheless, we know relatively little about the role of non-state actors and their cooperation with the state in Russian migration policy. This paper addresses this gap and presents a differentiated picture of the conditions under which experts and state organizations interact in Russia's authoritarian environment. Thus, it attempts to understand why the relationship has entered a crisis following the major migration events in Russia and Europe after 2014.

\section{Theory and Methods: Experts, Power and Trust}

In this paper, experts are understood as 'persons of whom it is assumed that, based on their routine contact with specific topics, they have accumulated experience in contexts relevant for taking action'- more precisely political action (Stehr, Grundmann 2011:x). Such a broad definition encompasses not only scientists, but also NGOs that possess useful knowledge due to their activities in the field of migration, i.e. knowledge that increases the 'capacity to take social action' in the eyes of the recipients (ibid:2). A productive relationship presupposes, among other things, that the political recipients are convinced of the reliability and validity of the expertise, which implies that they trust the experts.

Experts can be regarded as influential actors, even if they do not have political power to act. Ulrich Beck and Wolfgang Bonß (1989:386) emphasized the discursive influence of the social sciences in defining social reality and problems. This also applies to experts beyond the scientific community 
who affect political decision-making by selecting, weighting and interpreting reality (Stehr, Grundmann 2011:119). Beyond the discursive influence of expert knowledge, experts can influence the political sphere through direct interaction, such as policy advice or in the context of legislative procedures (Warsewa et al. 2020:294). However, expert knowledge does not replace established political processes. Political decisions remain in the logic of the political sphere. Therefore, it cannot be assumed that expert knowledge flows unhindered and unchanged into the political process and instead tends to have a 'diffuse, gradual and indirect impact on policy' (Boswell 2009:5).

These considerations can be applied to the Russian case, specified in relation to the field of migration policy, and expanded with regard to the conditions of the political authoritarian regime. The analysis is based on thirty semi-structured interviews with individuals or representatives of organizations involved in migration policy (Table 1). The interviews were conducted in the period between September 2017 and March 2019 during four fieldwork stays in Moscow. They were conducted and transcribed in Russian and then analysed through a data-driven inductive analysis, supported by the software MAXQDA. All interviews were pseudonymized, and the quotes cited in this paper were translated into English.

\section{Table 1}

Number of Expert Interviews by Type of Organization

\begin{tabular}{l|c}
\hline \multicolumn{1}{c|}{ Type of Organization } & Quantity \\
\hline Individual Experts & 9 \\
Human Rights Organizations & 6 \\
Think Tanks & 5 \\
Diaspora Organizations & 4 \\
International Organizations & 3 \\
Social NGOs & 3 \\
\hline
\end{tabular}

\section{Collaboration before the Crisis}

Looking at the interactions between state and experts from the 1990s until 2010s, one can observe much evidence of cooperation in which state actors drew on societal expertise. During the 1990s, international organizations played a particularly important role in the development of migration policy, especially the asylum system. Russia was unprepared for the enormous influx of post-Soviet migrants after the USSR's disintegration and was willing to take advantage of Western expertise. The window of opportunity for political influence by experts seemed to be wide open at that time as long-term experts confirmed in the inter- 
views. The collaboration continued during the 2000s but shifted towards the regulation of 'labour migration'. Above all, the years 2006 to 2007 are remembered as the 'golden period' in terms of the partnership (Interview Kasakovthink tank, February 2018). At that time, Viatcheslav Postavnin was appointed Deputy Director of the Federal Migration Service by President Vladimir Putin and was entrusted, among other things, with the development and implementation of new migration legislation, which at times considerably facilitated the legalization of labour migrants and was celebrated as a 'liberal revolution' (Interview Abramova-individual expert, March 2018).

In addition, the IOM, the UNHCR and also local NGOs carried out capacity building measures, which in their view were oriented to 'Western standards' and adapted to the Russian context. For instance, during the 2000s close cooperation took place when the policy measure of Readmission and Voluntary Return of migrants was introduced. Ekaterina Afanasyeva, who works for an international organization in Moscow and who was involved in the development of the legal framework and the qualification of officials, summarized this cooperation:

The closest and most intensive collaboration with the FMS was when we together developed the policy of Readmission. This process lasted five to six years. First, we trained the staff on readmission issues and explained what this was good for $<\ldots>$ There were many working sessions, seminars and workshops. We helped to develop guidelines on how the centres should be built, and what conditions for migrants there should be (Interview Afanasyeva - international organization, February 2018).

A case in point of state-expert interaction in developing long-term strategies is the concept of state migration policy through to 2025, approved by the President in 2012. In an unprecedented way, experts were involved in the drafting of the strategy and particularly strengthened an economic and demographic perspective on migration. Aleksei Kapustin, a scholar of a high-ranking university, reported with particular enthusiasm:

The role of the experts in 2012 was very important. There was an expert group at the Higher School of Economics, which consisted of about 100 people. These included not only migration scientists, but also pedagogues, economists, sociologists, those who in one way or another deal with the issues of migration. Representatives of public and international organizations, the economy and trade unions were present. This concept was developed by experts (Interview Kapustin- individual expert, March 2019).

Subsequently, many experts were also involved in the implementation of the newly developed migration policy instruments. For example, in the establishment of the Sakharovo Multifunctional Migration Centre, where the application for the newly developed instrument 'patent'1 takes place, or in the

\footnotetext{
${ }^{1}$ Since 2015, foreigners who arrive from countries with visa-free entry to Russia do not have to obtain work permits, but simpler 'patents' for their work, regardless of whether they want to be employed by an individual (entrepreneur) or an organisation (Denisenko 2017).
} 
development of the obligatory language test, which is necessary for obtaining a patent. Finally, ironically, the dissolution of the Federal Migration Service and its incorporation into the Ministry of Internal Affairs, which marked a rapid break in the interaction between officials and experts, can be attributed at least in part to the expertise of a think tank. Oleg Romanov, an expert from a think tank that is well connected to state circles, reported in an interview that his organization had carried out a detailed analysis on behalf of the state on the effectiveness of the FMS before the restructuring, which had come to a devastating conclusion:

In 2015 we completed an analysis on the situation of migration commissioned by the state, in which we concluded that the Federal Migration Service did not adequately address the migration situation in the country at that time and will probably not be able to fulfil the tasks set by the state in future. Our opinion was that it should be dissolved. Three months later it was dissolved. I do not know whether, on the basis of our analysis or not. But I think we played a role (Interview Romanov- think tank, September 2017).

However, it must be emphasized that the experts' recommendation was by no means to incorporate it into the Ministry of Internal Affairs, which almost all experts considered a major mistake, but rather to integrate it into the Ministry of Economic Development.

\section{Limitations within an Authoritarian Environment}

As the examples above show, non-state experts have been intensively involved in Russian migration policy since the early 1990s. In particular, they were involved in the development of long-term strategies, but they also advised state officials on the implementation of policies. International Organizations, such as the IOM or the UNHCR, even qualified state authorities in line with Western standards.

According to my interviewees, however, a self-determined influence on migration policy is very limited due to the dominant position of the state and a political culture that places experts and state officials in a strict hierarchical relationship. This is manifested in the narrow framework in which experts can develop policy proposals. State actors control and manage policy networks by defining narrow tasks whereby experts can facilitate political objectives, but can hardly contribute independent ideas that oppose government policy. The political utilizations of expert knowledge by state organizations is also extremely selective. Sergei Makarov, a leading scholar in the field of demography, explained that policy proposals are only considered if they are in line with existing political intentions. Due to a lack of political competition, the actual impact of expertise remains largely dependent on the ruling elites (Interview Makarov- individual expert, October 2018). 
Another limiting condition of state-expert interaction consists in the weak dialog that characterizes political culture in Russia. As a rule, experts do not receive feedback from officials on whether their policy recommendations have been taken into account. This is also the experience experts make at roundtables with state actors, which is seen as an imitation of dialogue without a real exchange of ideas.

Russian political culture is also characterized by the enormous importance of personal contacts and the relevance of individual persons within state organizations. Experts gain influence above all if they have personal contacts with influential officials. This goes along with a strong dependence on the goodwill and personal relationships with individual ministers or officials. Anastasiya Panova, a representative of a well-known human rights organization, reported that her public criticism regarding corruption in the area of migration had led to an extreme deterioration in her relationship with the official responsible for migration at the time. Indeed, she reported that she sometimes makes strategically positive statements about certain officials in order to be heard by them in return (Interview Panova - human rights organization, October 2018). The dependence on personal contacts also explains the fragility of relations between state officials and experts. Several experts reported that changes of ministers or the restructuring of state organizations have resulted in the loss of essential personal contacts that had previously facilitated the cooperation with state authorities:

Reshetnikov left his post, and the person who took his place doesn't even ask for our expertise - he doesn't contact us at all $<\ldots>$ Today everything [concerning the Sakharovo Centre] is decided by the director of the Government Department for Economic Development, and he is not interested in interacting with us $<\ldots>$ maybe he mistrusts the NGOs, I don't know (Interview Kasakov- think tank, February 2018).

Furthermore, expert organizations operate within an extremely limited financial framework. This makes them particularly dependent on project-related state funding, such as presidential grants. In this context, the Federal NGO Law of 2006 and the Law On Foreign Agents of 2012 are highly problematic because they severely restrict foreign funding of non-governmental organizations (Aasland et al. 2016; Crotty et al. 2014). The label of 'foreign agent' exerts pressure on critical civil society organizations not only through the administrative paperwork, but also as a stigma that keeps officials from collaborating with these NGOs. Danil Vasiliev, director of a Moscow think tank, explains how the label 'foreign agent' enforces loyalty to state power:

Many foreign organizations, almost all of them, have been blocked. One must now inform whether one has foreign donors. If you receive grants from foreign organizations, you will be given the title of a foreign agent. The label of foreign agent has the meaning of espionage in our political mass consciousness. It is such an organization that carries out subversive activities in 
the interest of world imperialism. This is a sad story. It is very complicated for public organizations. Many are forced to simply pretend the highest degree of loyalty to the authorities in order to somehow exist, in order to get subsidies. <..> All major available grants are called Presidential Grants and are distributed directly by the Kremlin. It is politically motivated who gets them and who doesn't (Interview Vasiliev - think tank, March 2019).

Even though experts cannot exercise direct political influence even in democratic political systems, the Russian case shows some specific characteristics of authoritarian control of expert policy networks. These include the sanctioning of foreign financing, which makes experts more dependent on the state. In addition, weak dialog between state and experts, non-transparent political decisions and the absence of institutionalized political competition are specific characteristics of the authoritarian context. Finally, an extremely personalized system of interaction between state and society places experts in a relationship of dependence in which substantial criticism of political decisions is prevented and loyalty is forced.

\section{Securitization and State Monopolization}

The armed conflict in Ukraine, beginning in 2014, which forced a large portion of the population of Donbas to flee, including one million who moved to Russia (Kuznetsova 2020), together with the intense public debate in Russia about the so-called 'European migration crisis', has given new impetus to Russian migration policy. In spring 2016, a tremendous change in Russian migration policy took place when the Federal Migration Service (FMS) was abolished and its functions were transferred to the Ministry of Internal Affairs. Even though this decision cannot be considered only as a reaction to the 'European migration crisis', the intensive public debate on this matter seems to have significantly contributed to an increasing securitization of Russia's migration policy:

I think that the dissolution of the Federal Migration Service of Russia and the transfer of the function to the Ministry of Internal Affairs was caused by the fact that there was a serious migration crisis in the European states. The emphasis of migration management shifted [towards security] $<\ldots>$ The advantages of institutional restructuring are obvious: the aim was to avoid a situation like that in the European states (Interview Melnikov- individual expert, October 2018).

One year later, a draft decree for a new migration strategy, supposed to replace the former state migration concept of 2012, was signed by President Putin. The new project, which was developed behind closed doors by the Ministry of Internal Affairs, showed a much stronger security focus and was aimed at preventing 'undesirable external migration' and avoiding the 'abuse of immigrants' right to asylum' (Garant 2017). Moreover, it suggested the need to 'expand the list of legal instruments for containing and regulating migration flows from countries 
with unstable social, political and economic conditions' (ibid). At the end of 2018, the final version of this new concept of state migration policy, targeting the short period between 2019 and 2025, came into force (Kremlin 2018).

According to nearly all of the interviewed experts, these changes seriously affected the nature of the Russian migration regime. Especially the organizational reform that integrated the responsibility for migration into the Ministry of Internal Affairs has been heavily criticized by experts, because it threatened to replace the long-term strategy of migration management and integration with an exclusive focus on control and restriction. Aleksander Tarasenko, head of a diaspora organization in Moscow, expressed his concerns about the new organizational responsibility as follows:

Who deals with migration? No one. When there was the Federal Migration Service, it was formally responsible. Then it was disbanded and handed over to the Ministry of Internal Affairs. And this body, the Ministry of Internal Affairs, has only one job: to monitor and control. Arrest and punish, punish for violations (Interview Tarasenko - diaspora organization, September 2017).

In addition, a radical break in the relationship between the state and experts occurred. Most of the interviewed experts reported that since the institutional restructuring, they have had little opportunity to interact with the officials now responsible for migration. According to Igor Rodin, a prominent migration scholar, this is also related to a general change in the nature of decision-making in recent years:

And in the last two or three years this has become even more noticeable in all areas - the mechanism of decision-making itself has changed. If there was any element of discussion in the past $\langle\ldots$.$\rangle it no longer exists today. Somewhere$ in a close circle [decisions are made], i.e. probably some selected experts are invited - the preferred, most loyal experts (Interview Rodin- individual expert, February 2018).

This also affected the development of political strategies in the field of migration. A case in point is the new migration state concept, which, according to the experts interviewed, unlike 2012, was developed without the participation of independent migration experts and was not discussed in public. The publication of the new concept came as complete surprise, at least for many of the experts who were involved in the previous concept. Moreover, the scope for action for non-state actors has become extremely narrow, especially for internationally active organizations. The UNHCR had to stop the training it has been conducting for more than two decades on capacity building in asylum law. The activities of international organizations, which were so important for migration policy in the 1990s and the 2000s, have been considerably curtailed, as Guzel Lebedeva, director of an international organization, emphasized:

In the last four years $<\ldots>$ since 2014 there have been many restrictions. Before, there was much more freedom. Since then, many international organizations 
have closed and left the country. For example, the IOM, the International Organization for Migration, has severely restricted its activities, many people have lost their jobs. The UNHCR could also be more active, the Red Cross. Yes, of course. The Open Society Foundation has been closed. There have been many such changes in recent years (Interview Lebedeva- international organization, March 2019).

In summary, it can be said that the increased relevance of forced migration in Russia together with international events has led to a strengthening of security and control elements in migration policy and to a drastic break in cooperation with non-governmental expert organizations. Thus, the Russian migration regime has lost important elements of societal monitoring, feedback and advice. Not all experts perceive and criticize this restriction with the same intensity. While some experts, especially social NGOs, see their role only in 'helping' the state and tend to agree with their subordinate position, others, such as human rights organizations, claim an egalitarian role: 'We are citizens of Russia, we no longer live in Soviet times, we have the opportunity to speak and we do so. <...> After all, the government is there for us, not us for them. They must listen to us!' (Interview Panova - human rights organization, September 2017). This statement reflects an understanding of one's own role as an expert, which is linked to the promise of democracy, in which the state represents the people and must therefore listen to them. Overall, the spectrum of self-understandings expressed by the experts, ranging from 'helping' to 'influencing', shows that the role of the experts in an authoritarian environment is not simply being loyal, but is constantly being negotiated and adapted within given limits.

\section{Reasons for the Change}

How can this dramatic change in Russian migration policy be explained? Why did the hierarchical but interdependent cooperation between state and experts stop working? And this in a phase that, if not a crisis, must at least be evaluated as a situation marked by strong uncertainties. Based on the characteristics of state-expert interaction elaborated above, I argue that the reasons for the change are related to a threefold loss of trust in the usefulness of the expertise of non-state and particularly international expert organizations. This loss of trust can be explained firstly by a collision of the long-term logic of expert advice with the short-term crisis management of the state; secondly by a dynamic that followed from the institutional restructuring of the Federal Migration Service that dissolved long-standing personal relationships between experts and officials; and thirdly by a general loss of trust in Western recipes and liberal norms in the management of migration (crises).

First, as pointed out above, the political utilization of expert knowledge in Russia only takes place when expert positions overlap with the government's political objectives. Since, in light of international migration events, political 
objectives have shifted even more strongly than before toward national security, it can be assumed that the political demand for expertise has also changed toward this direction. Therefore, it can be assumed that the previously dominant expert community who had supported liberal policies has lost importance in recent years. In addition, the short-term political logic of crisis management seems to collide with the long-term perspective of expert positions. Whereas earlier strategy papers were concerned with developing a long-term perspective for the recruitment and integration of migrants, during the crisis the focus was laid on developing immediate measures that can stop unwanted large-scale migration. The migration scholar Sergei Makarov put it the following way:

In my opinion, they are not at all interested in the opinion of the experts, because they see their task as simply not letting migrants in or limiting the influx of migrants. That is all. But from the perspective of the concept, and even more so from the assessment of the situation, they should on the contrary be assessed according to how many migrants they were able to attract and integrate. But this is not the case (Interview Makarov-individual expert, October 2018).

With the new emphasis on security, confidence in the usefulness of expertise aimed at the long-term recruitment and integration of 'labour migrants' seems to have been broken and lost its instrumental value. This is confirmed by the fact that in cases where expertise and political intention still overlap, such as in the case of settlement in the Far East and the naturalization of 'compatriots', collaboration between state officials and experts still exists.

Second, since cooperation between state officials and experts in Russia is based largely on personal relationships of trust, the institutional restructuring has led to the dissolution of many of the relationships that have shaped policy networks in recent years. Natalia Bolshakova, an employee of a religious NGO, described the problem in detail:

The problem is the closed system. The system itself is closed, and it is therefore very difficult to establish contact with them [Ministry of Internal Affairs]. Basically, everything in Russia is based on personal contacts. I don't know what it is like in Europe. But here, unfortunately, people are afraid to get in contact with NGOs. It is very difficult. $<\ldots>$ We had very good personal contacts $<\ldots>$ We try to [establish new contacts], in very small, small steps $\langle\ldots>$ Because it's very easy to ruin a relationship because politics is constantly changing. It's all very hard (Interview Bolshakova- social NGO, September 2017).

The interview excerpt also shows that the closed structure of the Ministry of Internal Affairs makes it extremely difficult and time-consuming to establish new relations.

Third, against the background of strained relations with the West, a significant loss of confidence in the internationally active and networked organizations seems to have developed. This points to a general loss of trust and legitimacy in 
Western recipes and standards, caused in part by the perceived European refugee crisis. The statement of Vitaly Melnikov, a high-ranking expert with good contacts to the authorities due to his former work in the Federal Migration Service, also indicates a change in the relationship with Europe, in which Russia wants to emancipate itself from the role of catching up:

\begin{abstract}
We have learned much, particularly on issues of humanitarian status, the granting of asylum and refugee status. My people have been on business trips to the Federal Agency, to the Ministry of Labour. I prepared a series of agreements with the German Ministry of Labour. $<\ldots$.. $>$ That was in the nineties. But now I think there is something to learn from us. After all, there was no tragedy in Russia. It was difficult, hard; more [refugees] came to us than to all European countries together. But there was no tragedy. And in Europe there was a tragedy. So, I think now there is something to learn from us (Interview Melnikov-individual expert, October 2018).
\end{abstract}

Thus, while in the 1990s international organizations enjoyed a particularly high reputation for their Western expertise, today there is a tendency to establish one's own principles of migration management independent of the West. Internationally networked or financed experts seem to have become superfluous in this process.

\title{
Conclusion
}

This paper has analysed the role of experts in shaping migration policy in Russia and has worked out the conditions of collaboration with the state in an authoritarian environment. It shows that since the 1990s the Russian state has utilized expert knowledge to design long-term strategies and facilitate the development and implementation of migration policy instruments. However, state-expert interaction is characterized by steep hierarchies and is subject to strict control mechanisms by the state.

The increased significance of forced migration since 2014 as a result of the armed conflict in Ukraine together with the intensive public debate about a so-called 'European migration crisis' has even more securitized Russia's migration regime. This has been accompanied by a state monopolization of migration policy. As a result, the interaction between state and experts has experienced a major break, which caused a loss of societal control, feedback and advice. Such a development in a situation marked by great uncertainty can be explained by a threefold loss of confidence on the part of the state in the usefulness of non-governmental and especially international expertise. It has been argued that the loss of trust was triggered by the clash between the longterm logic of expert advice and the short-term crisis management of the state; by the interruption of long-standing personal relationships due to the dissolution of the Federal Migration Service as well a loss of trust in Western recipes and liberal norms in the management of migration. 
Given the ongoing tense situation between Russia and the 'West' as well as the internal polarization of Europe in dealing with forced migration and refugee protection, I assume that the role of international organizations such as the UNHCR in particular will continue to decline in the future and that international standards will therefore become less important for Russian migration policy in the long term.

\section{References}

Aasland A., Berg-Nordlie M., Bogdanova E. (2016) Encouraged but Controlled: Governance Networks in Russian Regions. East European Politics, 32 (2): 148-169.

Beck U., Bonß W. (1989) Weder Sozialtechnologie noch Aufklärung?: Analysen zur Verwendung sozialwissenschaftlichen Wissens. Frankfurt am Main: Suhrkamp.

Berg-Nordlie M., Holm-Hansen J., Kropp S. (2018) The Russian State as Network Manager: A Theoretical Framework. In: S. Kropp, A. Aasland, M. Berg-Nordlie, J. Holm-Hansen, J. Schuhmann (eds.) Governance in Russian Regions. Cham: Springer:7-42.

Boswell C. (2009) The Political Uses of Expert Knowledge: Immigration Policy and social Research. Cambridge: Cambridge University Press.

Brubaker W. R. (1992) Citizenship Struggles in Soviet Successor States. International Migration Review, 26 (2):269-291.

Cook L. J. (2013) The Political Economy of Russia's Demographic Crisis. In: N. Robinson (ed.) The Political Economy of Russia. Lanham, MD: The Rowman \& Littlefield:97-119.

Crotty J., Hall S. M., Ljubownikow S. (2014) Post-Soviet Civil Society Development in the Russian Federation: The Impact of the NGO Law. Europe-Asia Studies, 66 (8): 1253-1269.

Denisenko M. (2017) Migration to Russia and the Current Economic Crisis. In: A. Pikulicka-Wilczewska, G. Uehling (eds.) Migration and the Ukraine Crisis. Bristol: E-International Relations Publishing: $129-148$.

Garant (2017) Proekt Ukaza Prezidenta Rossiyskoy Federatsii 'Ob utverzhdenii Kontseptsii migratsionnoy politiki Rossiyskoy Federatsii' (podgotovlen MVD Rossii 28.06.2017) [Draft Decree of the President of the Russian Federation 'On Approval of the Concept of Migration Policy of the Russian Federation']. Available at: https:/www.garant.ru/products/ipo/prime/ doc/56617992/ (accessed 15 October 2020).

Heusala A. L. (2018) The Soviet Legacy of 'National Security' in Russian Migration Policy. Russian Politics, 3 (3): 430-450.

Kremlin (2018) Ukaz 'O Kontseptsii gosudarstvennoy migratsionnoy politiki Rossiyskoy Federatsii na 2019-2025 gody' [Decree 'On the Concept of State Migration Policy of the Russian Federation for 2019-2025']. Available at: http://www.kremlin.ru/events/president/ news/58986 (accessed 15 October 2020).

Kropp S., Aasland A., Berg-Nordlie M., Holm-Hansen J., Schuhmann J. (2017) Governance in Russian Regions: A Policy Comparison. Cham: Springer. 
Kropp S., Schuhmann J. (2014) Hierarchie und Netzwerk-Governance in russischen Regionen. Zeitschrift für Vergleichende Politikwissenschaft, (8): 61-89.

Kuznetsova I. (2020) To Help 'Brotherly People'? Russian Policy Towards Ukrainian Refugees. Europe-Asia Studies, 72 (3):505-527.

Kuznetsova I., Round J. (2019) Postcolonial Migrations in Russia: The Racism, Informality and Discrimination Nexus. International Journal of Sociology and Social Policy, 39 (1/2): 52-67.

Light M. (2016) Fragile Migration Rights: Freedom of Movement in Post-Soviet Russia. London: Routledge.

Malakhov V., Simon M. (2018) Labour Migration Policy in Russia: Considerations on Governmentality. International Migration, 56 (3): 61-72.

Migration Data Portal (2019) Main Page. Available at: https://migrationdataportal.org/?i=stock abs_\&t=2019 (accessed 15 October 2020).

Rosstat (2019) Demography. Available at: https://rosstat.gov.ru/folder/12781 (accessed 15 October 2020).

Round J., Kuznetsova I. (2017) Necropolitics and the Migrant as a Political Subject of Disgust: The Precarious Everyday of Russia's Labour Migrants. In: M. B. Jørgensen, C.- U. Schierup (eds.) Politics of Precarity. Boston: Brill: 198-223.

Schenk C. (2018) Why Control Immigration?: Strategic Uses of Migration Management in Russia. Toronto: University of Toronto Press.

Stehr N., Grundmann R. (2011) Experts: The Knowledge and Power of Expertise. Oxon: Routledge.

Warsewa G., Bleses P., Güldner M. (2020) Der Transfer von sozialwissenschaftlichem Wissen als Forschungsgegenstand. Soziologie, 49 (3): 287-307. 